\title{
SCIENCE AND CONSCIENCE
}




\section{Stanford Nuclear Age Series}

- General Editor, Martin Sherwin

A D V IS OR Y B O A R D

Barton J. Bernstein and David Holloway 


\title{
SCIENCE AND CONSCIENCE
}

The Life of James Franck

\author{
J O S T L E M M E R I C H
}

Translated by Ann M. Hentschel

Stanford University Press, Stanford, California 


\section{Stanford University Press}

Stanford, California

English translation (C20 I I by the Board of Trustees of the Leland Stanford Junior University. All rights reserved.

Science and Conscience was originally published in German under the title Aufrecht im Sturm der Zeit: Der Physiker James Franck, I882-1964 (C2007 GNT-Verlag:

Verlag für Geschichte der Naturwissenschaften und der Technik. All Rights Reserved. This translation is published by arrangement with the Publisher.

Foreword (C)20 I by the Board of Trustees of the Leland Stanford Junior University. All rights reserved.

No part of this book may be reproduced or transmitted in any form or by any means, electronic or mechanical, including photocopying and recording, or in any information storage or retrieval system without the prior written permission of Stanford University Press.

Printed in the United States of America on acid-free, archival-quality paper

Library of Congress Cataloging-in-Publication Data

Lemmerich, J. author.

[Aufrecht im Sturm der Zeit. English]

Science and conscience : the life of James Franck / Jost Lemmerich ; translated by Ann M. Hentschel.

pages $\mathrm{cm}$.-- (Stanford nuclear age series)

"Originally published in German under the title Aufrecht im Sturm der Zeit: Der Physiker James Franck, I 882-I964."

Includes bibliographical references and index.

ISBN 978-0-8047-63 I0-3 (cloth : alk. paper)

I. Franck, James, I882-I964. 2. Physicists--Germany--Biography. 3. Nobel Prize winners--Germany--Biography. 4. Jewish refugees--United States--Biography.

I. Hentschel, Ann, translator. II. Title. III. Series: Stanford nuclear age series.

QCi 6.F67L455I3 20 I I

530.092--dc22

[B]

2011007309

Typeset by Bruce Lundquist in Io/I 2.5 Times Roman 
This volume is dedicated to the memory of Lisa and Hermann Lisco, Dagmar and Arthur R. von Hippel, and Heinz Kallmann, whose cooperation and contributions made it possible. 
